\title{
Performance traits in different generations of imported Danish Landrace pigs
}

\author{
Ramutis Klimas and Asta Klimienè \\ Biological Research Centre, Faculty of Natural Sciences, Šiauliai University, Šiauliai, Lithuania
}

\begin{abstract}
The number of foreign pig breeds imported to Lithuania has increased, especially Landraces. Animals imported from other countries get into different environmental conditions. Decisions about adaptation of Danish Landraces were made when analysing the changes in the data for productivity of imported pigs and their offsprings of $F_{1}-F_{6}$ generations born in Lithuania. The work was carried out in the years 1998-2006. Because of adaptation to new environmental conditions, litter size, litter weight of piglets at 21 days of age and survival rate percent of piglets for primaparous sows of Danish Landrace breed, born and grown in Lithuania, was improving, in comparison with imported primaparous sows. According to evaluation data analysis of the control fattening and carcass for Danish Landrace progeny born in the country, offspring of sixth generation $\left(\mathrm{F}_{6}\right)$ distinguished by the best fattening performance. However, tendency manifested, that with increasing daily gain in many cases meatiness traits of pigs are getting worse. Muscularity of $F_{6}$ Landraces was $1.7-2.9 \%$ lower than of $\mathrm{F}_{2}-\mathrm{F}_{5}$ progeny of this breed $(P<0.05-0.01)$. Therefore, when striving in the adaptation process to stabilise specific traits of Landrace pigs, especially fattening performance and meatiness, besides balanced feeding and making of good keeping conditions, it is also purposeful regularly to import boars (each 3-4 years) of this breed into breeding centres or to use Al stations services.
\end{abstract}

Keywords: Pig, Danish Landrace, adaptation, generation, litter performance, fattening performance, carcass quality

\section{Zusammenfassung}

\section{Leistungsentwicklung nach mehreren Generationen von importierten Schweinen der Dänische Landrasse}

Untersucht wurde die Leistungsentwicklung von nach Litauen importierten Schweinen der Dänischen Landrasse nach mehreren Generationen. Erfasst wurden Leistungen der importierten Tiere sowie deren Nachkommen der Generationen $\mathrm{F}_{1}-\mathrm{F}_{6}$ aus den Jahren 1998 bis 2006 mit den Merkmalen Wurfgröße, Wurfgewicht am 21. Tag und Aufzuchtrate bei Jungsauen. Gegenüber der Importgeneration konnte tendenziell ein positiver Trend der Wurfleistungen beobachtet werden. Im Ergebnis der Nachkommenprüfung auf Mast- und Schlachtleistungen konnten in den Generation $\mathrm{F}_{4}$ bis $\mathrm{F}_{6}$ eine positive Leistungsentwicklung beobachtet werden. Die Rückenspeckdicke erhöhte sich bis $z u F_{6}$ und die Schlachtkörperqualität zeigte mit 
Ausnahme der $\mathrm{F}_{6}$ Tiere leicht verbesserte Werte. Um das Qualitätsniveau zu halten wird empfohlen alle 3 bis 4 Jahre Eber der Dänischen Landrasse zu importieren.

Schlüsselwörter: Schwein, Dänische Landrasse, Anpassung, Generation, Wurfleistung, Mastleistung, Schlachtkörperqualität

\section{Introduction}

At Lithuanian breeding centres about $40 \%$ of all purebred pigs were Landrace, $34 \%$ - Large White (Yorkshire), $21 \%$ - Lithuanian White open population, $4 \%$ - Duroc and Pietrain paternal breeds, $1 \%$ - Lithuanian White old genotype and Lithuanian native gene pool (Rimkevičius et al. 2009). Recently, the number of foreign pig breeds imported to Lithuania has increased, especially Landraces. Lithuanian law acts ascribe Landrace breed as intermediate performance breed (Saikevičius 2003). Accordingly to that, possibilities of Landraces use are the biggest of all pigs bred in Lithuania.

Animals imported from other countries get into different environmental conditions (climate, feeding, housing) and strive to survive. It is supposed that reproductive, fattening and meatiness traits (phenotype) of pigs depend on environmental conditions even up to $60 \%$, and only up to $40 \%$ depend on genotype (Close 1970, Curtis 1983, Verhagen 1987, Cameron 1993, Diekman et al. 1994, Verstegen \& Close 1994, Lynch \& Walsh 1998, Bizelis et al. 2000, Röhe et al. 2000, Hoste 2003, Köck et al. 2009). Therefore, after changing environmental conditions, the productivity of animals often gets worse (Cameron 1993, Lynch \& Walsh 1998, Hoste 2003). This is related to the natural resistance of organism against unfavourable influences. If new conditions are very different from the earlier ones, adaptation can last even through several generations. During this period weaker animals die and only those adapted normally to new conditions survive. Adaptation, like reproduction, is directed towards survival. Provided the environmental conditions are favourable, all the processes may even have an improving effect on the animals. However, if more energy has to be spent on survival, performance dramatically falls down, especially that of highly productive animals (Kasprzyk 2007a, 2007b). Besides that, the course of adaptation depends on the breed of animals and on individual features: type of nervous system, stress-resistance and age (Cameron 1993, Hoste 2003, Kriauzienè et al. 2005, Klimienè \& Klimas 2007, Vostry et al. 2009, Klimas \& Klimienè 2009, Fördös et al. 2010). Thus, adaptation of imported pigs of different breed under new environmental conditions should be investigate.

The aim of this work was to investigate changes of the reproductive traits, fattening performance and meatiness in different generations of Danish Landrace pigs during their adaptation process in Lithuania.

\section{Material and methods}

Decisions about the adaptation of Danish Landraces were made when analysing changes in productivity data of the imported pigs and their offsprings born in Lithuania. Various breeding records for the years 1998-2006 have been studied (pedigree certificate of imported progeny, sow farrowing and offspring records, control fattening and slaughter data). 
Danish Landrace gilts from 16 families and young boars from three lines were imported from Denmark and located to farmer A. Matusevičius Breeding Centre (Šakiai district) in the year 1998. Imported and born (local) Danish Landrace gilts and sows in this breeding centre were inseminated with Danish Landrace boars. Microclimate in stables was regulated by computerized equipment. During the observation period, the temperature in the lodgements for farrowing sows was costantly $19^{\circ} \mathrm{C}$, for pedigreed progeny $-21^{\circ} \mathrm{C}$, for piglets up to $26^{\circ} \mathrm{C}$. The relative air humidity was $70 \%$. Up to $8-12$ farrowing sows and up to 15 pedigreed gilts were kept in stalls. The pigs were kept on grid floor, and the stalls were not littered.

The pigs were fed with a balanced compound feed. Progenies till $20 \mathrm{~kg}$ of weight were fed with feed brought from the Netherlands. The piglets from 10 to 20 days of age were received pre-starter feed »Promote WF « containing $18.4 \%$ of proteins, $10 \%$ of fat and $0.5 \%$ of fibre per $1 \mathrm{~kg}$. Later, piglets received starter feed »Porcipart AP« containing $18.5 \%$ of proteins, $6.5 \%$ of fat and $2 \%$ of fibre per $1 \mathrm{~kg}$ at 20 to 40 days of age. The progenies till $20 \mathrm{~kg}$ of weight (approx. 65 days of age) received compound feed "Proresponce".

From $20 \mathrm{~kg}$ of weight the pigs were already fed with compound feed made in the stock company "Lekèčiai" (Lithuania). One kilogram of feed for the pedigreed gilts of $20-40 \mathrm{~kg}$ of weight contained $13.8 \mathrm{MJ}$ of of metabolizable energy and $18.5 \%$ of proteins, for pedigreed gilts of over $40 \mathrm{~kg}$ of weight $13.5 \mathrm{MJ}$ and $17.5 \%$, respectively; for farrowing sows $12.3 \mathrm{MJ}$ and $12.5 \%$, respectively; and for lactating sows $13.2 \mathrm{MJ}$ of metabolizable energy and $17.2 \%$ of proteins. The weaned piglets (approx. 35 days of age) and the lactating sows were fed with dry compound feed, and pigs of other groups (pedigree progenies, farrowing sows) - with mash, served automatically.

\section{Number of investigated pigs}

Reproductive performance - litter size (number of piglets born alive), number and litter weight of piglets at 21 days of age, survival rate - of imported $(n=24)$ and born and grown in breeding centre $F_{1}(n=24), F_{2}(n=24), F_{3}(n=24), F_{4}(n=24)$ and $F_{5}(n=24)$ generations of primaparous sows of Danish Landrace breed were analysed. Additionally, data for the fattening performance and meatiness traits delivered $F_{1}(n=16), F_{2}(n=59), F_{3}(n=49), F_{4}(n=70)$, $F_{5}(n=39)$ and $F_{6}(n=10)$ Landrace breed progenies were recorded, systemised and analysed. According to the accepted methodology (Saikevičius 2003), the fattening performance and meatiness traits of the offspring of $243 \mathrm{~F}_{1}-\mathrm{F}_{6}$ generations of Danish Landraces were evaluated in control fattening stables of the State Pig Breeding Station.

\section{Fattening performance}

Piglets of Landrace breed were transported from the breeding centre to the fattening performance test station at the age of 77-85 days $(24-26 \mathrm{~kg}$ ). Four piglets (two gilts and two castrates) were selected from the same litter for control fattening, which was proceeded at $30 \mathrm{~kg}$ to approximately $100 \mathrm{~kg}$ live weight. Housing and feeding conditions were the same for all pigs. The pigs were kept in individual pens. The average air temperature was $18-20^{\circ} \mathrm{C}$ and the relative humidity was not higher than $70 \%$. During the control fattening, the animals were fed special dry compound feed twice a day. The feed was individually weighed for each pig. A kilogram of compound feed contained $13.84 \mathrm{MJ}$ of metabolizable energy and $16.0 \%$ of 
proteins. The pigs had free access to water for $24 \mathrm{~h}$. When the pigs were fattened to approx. $100 \mathrm{~kg}$ in weight, their age in days, average daily gain and feed conversion (metabolizable energy) per kg gain were estimated.

\section{Phenotypic evaluation of the pig leanness}

At the control fattening test station the pigs with about $100 \mathrm{~kg}$ live weight were measured with ultrasonic apparatus before delivered to meat-processing plant. The lean meat percentage was determined with Piglog 105 by measuring the backfat thickness ( $\mathrm{mm}$ ) on live pigs at two points and M. longissimus dorsi thickness (mm) - at one point (Piglog 105 User's Guide 1991):

1) between the $3 \mathrm{rd}$ and 4th last lumbar vertebrae and $7 \mathrm{~cm}$ sideways from the middle dorsal line (FAT-1);

2) $10 \mathrm{~cm}$ from the last rib towards the cranial part and $7 \mathrm{~cm}$ sideways from the middle dorsal line (FAT-2). The thickness of the loin lean (M. longissimus dorsi) was also measured at this point.

The lean meat percentage was calculated according by the in-coded Piglog 105 formula. Age (days) and live weight (kg) of pigs were introduced to the apparatus before testing.

\section{Control slaughter of pigs}

The control slaughtering of pigs at about $100 \mathrm{~kg}$ and evaluation of the carcasses were carried out at the one meat - processing plant. Carcass length (from cranial edge of first neck vertebra to anterior edge of the pubic bone), backfat thickness (at 6-7 rib and at the last rib), loin lean area (at the last rib) and ham weight of chilled carcasses (at $0 \ldots+4{ }^{\circ} \mathrm{C}$ in $24 \mathrm{~h}$ period) were recalculated according to $100 \mathrm{~kg}$ live weight of pigs, using accepted coefficients of regression (Saikevičius 2003).

\section{Statistical analysis}

The investigation data were processed using statistical package Statistica for Windows version 6.0 (StatSoft 2001) and according to the basic guide to the statistical analysis of biological data by Tucker (2003). The difference was considered statistically significant when $P<0.05$.

\section{Results and discussion}

The results of reproductive traits of different generations Danish Landrace sows presented in Table 1. After changing an environmental conditions, litter size of imported as well as born in Lithuania primaparous sows was statistically not reliably different. However, due to adaptation to new conditions, litter weight of piglets at 21 days of age was increasing and mortality rate of piglets was decreasing. Number of piglets at 21 days of age of $F_{1}-F_{5}$ Landrace sows had 0.8-1.5 piglets more, litter weight of $\mathrm{F}_{1}, \mathrm{~F}_{3}-\mathrm{F}_{5}$ generations was 4.9-7.0 kg, survival rate of piglets $\mathrm{F}_{1}, \mathrm{~F}_{2}, \mathrm{~F}_{4}$ and $\mathrm{F}_{5}$ generations was $6.0-8.1 \%$ higher, to compare with imported sows. It should be noted that litter weight between $\mathrm{F}_{1}-\mathrm{F}_{5}$ sows of Landrace breed was not reliably different, except $\mathrm{F}_{2}$ sows. 
Table 1

Reproductive performance of primaparous sows of Danish Landrace breed

\begin{tabular}{lcccccc}
\hline Item & Imported pigs & \multicolumn{5}{c}{ Generations of pigs born in Lithuania } \\
& & $\mathrm{F}_{1}$ & $\mathrm{~F}_{2}$ & $\mathrm{~F}_{3}$ & $\mathrm{~F}_{4}$ & $\mathrm{~F}_{5}$ \\
\hline No. of sows & 24 & 24 & 24 & 24 & 24 & 24 \\
Litter size & $11.0 \pm 0.2$ & $11.2 \pm 0.2$ & $11.2 \pm 0.1$ & $11.3 \pm 0.1$ & $11.6 \pm 0.1$ & $11.2 \pm 0.1$ \\
At 21 days: & & & & & & \\
No. of piglets & $9.4 \pm 0.2$ & $10.2 \pm 0.2^{\mathrm{a}}$ & $10.5 \pm 0.1^{\mathrm{b}}$ & $10.2 \pm 0.2^{\mathrm{a}}$ & $10.9 \pm 0.2^{\mathrm{c}}$ & $10.5 \pm 0.2^{\mathrm{b}}$ \\
Litter weight, $\mathrm{kg}$ & $51.2 \pm 1.4$ & $56.1 \pm 0.7^{\mathrm{a}}$ & $51.8 \pm 0.9$ & $56.7 \pm 1.2^{\mathrm{a}}$ & $58.2 \pm 0.7^{\mathrm{b}}$ & $58.1 \pm 0.5^{\mathrm{b}}$ \\
Survival rate, $\%$ & $85.8 \pm 1.5$ & $91.8 \pm 1.4^{\mathrm{a}}$ & $93.8 \pm 0.9^{\mathrm{b}}$ & $90.4 \pm 1.7$ & $93.9 \pm 1.3^{\mathrm{b}}$ & $93.8 \pm 1.3^{\mathrm{b}}$ \\
\hline
\end{tabular}

Significant effects to compare with imported pigs: ${ }^{\text {a }} P<0.05,{ }^{b} P<0.01,{ }^{c} P<0.001$

According to evaluation of control fattening and carcass data of Danish Landrace progenies born in Lithuania (Table 2) there was indicated, that due to adaptation process in new environmental conditions, only progenies of sixth generation $\left(F_{6}\right)$ showed superiority on fattening performance. To compare with Landraces of other groups $\left(F_{1}-F_{5}\right), F_{6}$ progeny reached $100 \mathrm{~kg}$ weight by $10-23$ days earlier, gained daily by $52-157 \mathrm{~g}$ more (to compare with $F_{1}$ differences is not statistically significant) and consumed $0.8-14.6 \%$ of compound feed per kg gain less (to compare with $\mathrm{F}_{1}$ and $\mathrm{F}_{2}$ differences are statistically significant). However, agreeably to the data by Kapelanski et al. (2000), Michalska et al. (2000), Pierzchala et al. (2003), Citek et al. (2006) and Stupka et al. (2006), with increasing daily gain the meatiness traits of pigs in many cases are worsening. Backfat thickness at 6-7 rib of $\mathrm{F}_{6}$ progeny was $6.1 \mathrm{~mm}$ thicker than of $\mathrm{F}_{1}$ progenies, and muscularity - 1.7-2.9\% lower than of $\mathrm{F}_{2}-\mathrm{F}_{5}$ progeny. Thus, for pigs of Danish Landrace breed in the course of adaptation were determined more variable changes of fattening and meatiness traits. It should be noted that productivity of investigated Landraces were partially maintained by insemination using semen of new lines of Landrace boars (kept in the Al stations) continusly imported to Lithuania.

Pig breeds in Lithuania are classified into three groups: maternal breed (Lithuanian native, Lithuanian White, Large White/Yorkshire), intermediate breed (Landrace) and paternal breed (Duroc, Pietrain and their hybrids with Landrace pigs). Because Landrace by the trend of productivity are ascribed to intermediary group, use of this breed is much wider compared with all of pigs bred in Lithuania. Therefore it is no coincidence that at breeding centres about $40 \%$ pigs are Landraces (Rimkevičius et al. 2009). The population of Landrace pigs in Lithuania to be comprised of German, Danish, Finnish, Swedish, Norvegian, Dutch and Frensh Landrace breeds. Striving to preserve specific traits of pigs of imported breeds, it is necessary to investigate influence of adaptation on their reproductive traits and fattening performance, and on meatiness. After analysing productivity traits and tendencie changes of imported and locally born (no less than of two - three generations) pigs, it was possible to determine which breed of pigs adapt better or worser to new environmental conditions. Beside Danish Landrace pigs, such researches were made with Finnish Yorkshires (Klimienè 1993), maternal C-line (imported from Poland, nurtured in company »Hypor " by using Large White and Hampshire breeds) and D-line (imported from Poland, nurtured in company "Hypor" by using Dutch and Swedish Landrace breeds) (Kriauzienè et al. 2005), English Large White, Swedish Yorkshire, Danish Duroc and Dutch Pietrain breeds (Klimienė \& Klimas 2007, Klimas \& Klimiené 2009). It was shown that the reproductive traits and fattening 
performance of Pietrain pigs breed were getting worse in the course of adaptation, whereas leanness, comparing $F_{1}$ and $F_{4}$ progeny, essentially did not changed. It is likely that Pietrains are most difficultly adapting to a new environmental conditions. However, Pietrain are used in combinations of commercial crossbreeding (hybridization) only as paternal breed.

Consequently, due to adaptation to new environmental conditions the litter size, litter weight of piglets at 21 days of age and percent of survived piglets of primaparous Danish Landrace sows born in Lithuania, were improved compared to the imported primaparous sows. Offspring of sixth generation $\left(\mathrm{F}_{6}\right)$ distinguished by the best fattening performance. However, muscularity of $F_{6}$ Landraces was $1.7-2.9 \%$ less than of $F_{2}-F_{5}$ progeny of this breed. Adaptation is a complicated process, therefore when striving to stabilise specific traits of Landrace pigs, and especially fattening performance and meatiness, besides balanced feeding and making of good keeping conditions, it is also purposeful regularly to import boars (each 3-4 years) of this breed into breeding centres or to use Al stations services.

Table 2

Control fattening and meatiness traits of Danish Landrace breed offsprings

\begin{tabular}{lcccccc}
\hline Item & \multicolumn{7}{c}{ Generations of pigs born in Lithuania } \\
& $F_{1}$ & $F_{2}$ & $F_{3}$ & $F_{4}$ & $F_{5}$ & $F_{6}$ \\
\hline No. of pigs & 16 & 59 & 49 & 70 & 39 & 10 \\
Age at 100 kg live weight, d. & $170 \pm 1^{\mathrm{b}}$ & $175 \pm 1^{\mathrm{c}}$ & $183 \pm 2^{\mathrm{c}}$ & $173 \pm 1^{\mathrm{b}}$ & $179 \pm 2^{\mathrm{c}}$ & $160 \pm 2$ \\
Daily gain, g & $932 \pm 30$ & $829 \pm 12^{\mathrm{c}}$ & $827 \pm 17^{\mathrm{b}}$ & $882 \pm 10^{\mathrm{a}}$ & $830 \pm 13^{\mathrm{b}}$ & $984 \pm 24$ \\
Conversion per kg gain: & & & & & & \\
Compound feed, kg & $2.98 \pm 0.03^{\mathrm{a}}$ & $2.95 \pm 0.03^{\mathrm{a}}$ & $2.89 \pm 0.04$ & $2.63 \pm 0.03$ & $2.62 \pm 0.04$ & $2.60 \pm 0.10$ \\
Metabolizable energy, MJ & $41.24 \pm 0.41^{\mathrm{a}}$ & $40.83 \pm 0.41^{\mathrm{a}}$ & $40.00 \pm 0.55$ & $36.40 \pm 0.41$ & $36.26 \pm 0.55$ & $35.98 \pm 1.38$ \\
Carcass length, cm & $99.5 \pm 0.3$ & $98.5 \pm 0.3$ & $97.2 \pm 0.3$ & $96.6 \pm 0.3$ & $98.6 \pm 0.2$ & $98.5 \pm 0.4$ \\
Backfat thickness: & & & & & & \\
At 6-7 rib, mm & $17.7 \pm 0.2^{\mathrm{c}}$ & $20.0 \pm 0.4^{\mathrm{a}}$ & $18.8 \pm 0.4^{\mathrm{b}}$ & $18.9 \pm 0.4^{\mathrm{b}}$ & $18.4 \pm 0.5^{\mathrm{b}}$ & $23.8 \pm 0.8$ \\
At last rib, mm & $-^{*}$ & $17.2 \pm 0.4$ & $15.5 \pm 0.4^{\mathrm{b}}$ & $16.0 \pm 0.3^{\mathrm{b}}$ & $15.3 \pm 0.3^{\mathrm{b}}$ & $19.2 \pm 0.7$ \\
Loin lean area, cm ${ }^{2}$ & $39.4 \pm 0.1^{\mathrm{b}}$ & $38.5 \pm 0.7^{\mathrm{b}}$ & $38.0 \pm 0.3^{\mathrm{c}}$ & $38.7 \pm 0.3^{\mathrm{b}}$ & $42.9 \pm 1.0$ & $43.4 \pm 0.8$ \\
Ham weight, kg & $11.9 \pm 0.1$ & $11.5 \pm 0.1$ & $11.4 \pm 0.1$ & $11.4 \pm 0.1$ & $11.7 \pm 0.1$ & $11.8 \pm 0.1$ \\
Lean meat \% (Piglog 105) & $-^{*}$ & $55.9 \pm 0.2^{\mathrm{a}}$ & $56.5 \pm 0.3^{\mathrm{b}}$ & $57.0 \pm 0.2^{\mathrm{b}}$ & $57.1 \pm 0.3^{\mathrm{b}}$ & $54.2 \pm 0.5$ \\
\hline
\end{tabular}

Significant effects to compare with $\mathrm{F}$ progenies: ${ }^{\mathrm{a}} P<0.05,{ }^{\mathrm{b}} P<0.01, \mathrm{c} P<0.001$, ${ }^{*}$ Evaluation backfat thickness at last rib and lean meat percentage (Piglog 105) of pigs fattened in control fattening stables of the State Pig Breeding Station was started from 2002, therefore $F_{1}$ progenies not having mentioned data.

\section{References}

Bizelis J, Kominakis A, Rogdakis E, Georgadopoulou F (2000) Genetic parameters of production and reproductive traits in on a farm tested Danish Large White and Landrace swine in Greece. Arch Tierz 43, 287-297

Cameron ND (1993) Methodologies for estimation of genotype with environment interaction. Livest Prod Sci $35,237-249$

Citek J, Stupka R, Sprysl M, Kluzakova E (2006) The effect of growth rates on carcass performance in pigs. Book of Abstracts 57th Annual Meeting EAAP, 232

Close WH (1970) Nutrition environmental interaction of growing pigs. Ph. D. Thesis, Queens Univ of Belfast, UK Curtis SE (1983) Environmental management in animals agriculture. lowa Univ Press, Ames, USA 
Diekman MA, Green ML, Clapper JA, Pusateri AE (1994) Environment and Reproduction. Principles of Pig Science, Nottingham Univ Press, UK, 319-331

Fördös A, Füller I, Bene S, Szabo F (2010) Weaning performance of beef Hungarian Fleckvieh calves. 3. Genotype $\times$ environment interaction. Arch Tierz 53, 123-129

Hoste S (2003) Genotype environment interactions. Perspectives in Pig Science, Nottingham Univ Press, UK, 25-39

Kapelanski W, Bocian M, Kapelanska J, Rak B (2000) Relation between growth rate and slaughter performance of pigs with different production ability. Book of Abstracts 51st Annual Meeting EAAP, 321

Kasprzyk A (2007 a) Characteristics of genetic parameters and genetic gain in breeding herd of PL pigs over 25-year breeding work period. Arch Tierz 50 Special Issue,107-115

Kasprzyk A (2007 b) Estimates of genetic parameters and genetic gain for reproductive traits in the herd of Polish Landrace sows for the period of 25 years of the breeding work. Arch Tierz 50 Special Issue, 116-124

Klimas R, Klimienè A (2009) Influence of environmental conditions on performance traits of imported pig paternal breeds. Zhiv nauki 4 (XLVI), 15-21

Klimiene A (1993) Acclimatization of the Finnish Yorkshire and their using for improvement of Lithuanian White pigs. Doctoral dissertation, Baisogala [in Lithuanian]

Klimienè A, Klimas R (2007) Adaptation of the English Large White and Swedish Yorkshire pig breeds in Lithuania. Vet Med Zoot 38, 28-32 [in Lithuanian]

Köck A, Fürst-Waltl B, Baumung R (2009) Effects of inbreeding on number of piglets born total, born alive and weaned in Austrian Large White and Landrace pigs. Arch Tierz 52, 51-64

Kriauzienè J, Macijauskas M, Masiulienè A (2005) The reproduction traits of maternal C and D lines pigs in the adaptation process. Proc 11th BABC, 84-86

Lynch M, Walsh B (1998) Genotype × environment interaction. Genetic analysis of quantitative traits, Sinauer Assoc, Inc, USA, 657-683

Michalska G, Nowachowicz J, Kapelanski W, Rak B (2000) Interrelationships between performance test characteristics in Polish Large White and Polish Landrace boars. Book of Abstracts, 51st Annual Meeting EAAP, 326

Pierzchala M, Blichorski T, Kuryt J (2003) Growth rate and carcass quality in pigs as related to genotype. Anim Sci Pap Rep 3, 159-166

Piglog 105 User's Guide (1991) SFK-Technology. Soborg, Denmark

Rimkevičius S, Rekštys V, Radienė Z, Sąlyga G, Jukna V, Saikevičienè B, Kerzienė S, Raudonikis A (2009) Pig breeding records 2008. State Pig Breeding Station, Baisogala, Lithuania [in Lithuanian]

Röhe R, Krieter J, Preisinger R (2000) The importance of variance components estimation in breeding of farm animals- a review. Arch Tierz 43, 523-534

Saikevičius KJ (2003) Set of the law acts, regulating animal breeding in the Republic of Lithuania. State Animal Breeding Supervision Service under the Ministry of Agriculture, Vilnius, 138-157 [in Lithuanian]

StatSoft (2001) Statistica for Windows version 6.0, Tulsa, Oklahoma, USA

Stupka R, Sprysl M, Cytek J, Okrouhla M (2006) The effect of growth rate to carcass formation in hybrid pigs. Book of Abstracts 57th Annual Meeting EAAP, 237

Tucker LA (2003) Simplistic statistics. A basic guide to the statistical analysis of biological data. Chalcomble Publications, Welton Lincoln

Verhagen JMF (1987) Acclimation of growing pigs to climatic environment. Ph. D. Thesis, Agric Univ Wageningen, The Netherlands

Verstegen MWA, Close WH (1994) The environment and the growing pig. Principles of Pig Science, Univ Press, Nottingham, UK, 333-353 
Vostry L, Pribyl J, Schlote W, Vesela Z, Jakubec V, Majzlik I, Mach K (2009) Estimation of animal × environment interaction in Czech beef cattle. Arch Tierz 52, 15-22

Received 9 May 2010, accepted 28 January 2011.

Corresponding author:

Ramutis Klimas

email: btmc@cr.su.It

Biological Research Centre, Faculty of Natural Sciences, Šiauliai University, P. Višinskio str. 19, LT-77156 Šiauliai, Lithuania 